\title{
Meski Lama di Kereta, Kamu Masih Bisa Bahagia
}

\author{
ASTRI HESTI CAHYANI, MUHAMMAD AKHYAR, HAYYU NIANDHINI, SIVA ALFIRA, \\ NABILA ANANDA, NAURA SEULANGA \\ Fakultas Psikologi, Universitas Pancasila \\ Email: malakhyar@gmail.com
}

\begin{abstract}
Abstrak: Penelitian ini bertujuan untuk melihat perbedaan kepuasan hidup pada pekerja komuter dan yang bukan pekerja komuter. Partisipan penelitian ini secara keseluruhan terdiri atas 94 pekerja yang bertempat tinggal di wilayah Bogor. Pengukuran kepuasan hidup dengan menggunakan The Satisfaction With Life Scale (SWLS) (Diener, Emmons, Larsen, \& Griffin, 1985). Hasil ini dapat disimpulkan bahwa tidak ada beda kepuasan hidup antara pekerja komuter dengan pekerja bukan komuter.
\end{abstract}

Kata Kunci: kepuasan hidup, pekerja komuter, kereta.

\section{PENDAHULUAN}

Ada sekitar 1,4 juta komuter dari daerah Bogor, Tangerang dan Bekasi yang setiap harinya berkegiatan di Jakarta (Badan Pusat Statistik, 2014). Dari keseluruhan, 69\% adalah komuter laki-laki dan $31 \%$ adalah komuter perempuan. Tak semua pekerja, $17 \%$ di antaranya adalah pelajar. Berdasarkan hasil survei jumlah komuter wilayah Bogor yang berkegiatan di luar kota Bogor sebanyak 428 ribu orang, sementara orang yang berasal dari luar Bogor yang berkegiatan di kota Bogor sebanyak 183 ribu orang (Irawan \& Pragesari, 2014).

Commuting merupakan bentuk perpindahan yang tidak tetap yang dilakukan commuter atau penglaju yang dilakukan secara ulang-alik dalam satu hari. Sementara seseorang yang bekerja dalam satu hari, biasanya mereka pergi pada pagi hari dan kembali pada sore hari atau di hari yang sama dan dilakukan secara terus-menerus setiap harinya disebut sebagai penglaju atau commuter
(Sari, 2017). Untuk mencapai ke tempat kerjanya, seorang pekerja commuter di Jabodetabek memiliki beragam moda transportasi, mulai dari sepeda, sepeda motor, mobil, kendaraan umum, kereta, bus kota atau Transjakarta (Setyodhono, 2017).

Menurut Hugo (dalam Warsida, 2013) pelaku mobilitas ulang-alik berdasarkan sudut pandang lokasi tempat tinggal ada dua jenis, yaitu autochthonous commuter dan allochthonous commuter. Autochthonous commuter merupakan penduduk luar kota yang melakukan kegiatan mobilitas ulang-alik ke pusat kota karena didorong oleh faktor ekonomi untuk bekerja. Motivasinya untuk kembali lagi ke daerah atau tempat tinggal asalnya adalah faktor keluarga dan budaya. Sedangkan, allochthonous commuter adalah penduduk yang pindah dari pusat kota ke pinggiran kota yang bertujuan untuk mendapatkan perumahan yang layak huni, harga perumahan yang relatif murah dan lingkungan yang bersih. Motivasi yang 
mendorong kegiatan ini untuk kembali ke daerah asalnya adalah faktor budaya dan keluarga.

Vanderslice \& Rice (1992) menyatakan bahwa para komuter memiliki banyak kesulitan dalam hidupnya. Hubungan perilaku komuter dengan stres sudah sangat jelas karena para komuter banyak kehilangan waktu dalam berkomuter dan merasa memiliki sedikit waktu untuk bekerja dan merasa pekerjaan yang selalu menumpuk dan memburu untuk segera diselesaikan (Vanderslice \& Rice, 1992).

Menurut Vanderslice dan Rice (dalam Rahmadana, 2014) kepuasan menjadi ukuran kualitas hidup para pelaku komuter, mulai dari kepuasan kehidupan pekerjaan, kehidupan berkeluarga, kepuasan waktu pribadi, kepuasan bersosialisasi dengan masyarakat dan kepuasan secara keseluruhan hidupnya. Para komuter menunjukkan memiliki kepuasan yang lebih rendah dalam kehidupan berkeluarga, memiliki kepuasan yang lebih rendah dalam hubungan rumah tangga, tidak memiliki waktu pribadi yang banyak, tidak memiliki waktu yang banyak untuk bersosialisasi dengan masyarakat sekitar tetapi memiliki kepuasan yang lebih dalam dunia pekerjaan. Namun, dapat dilihat, secara umum kepuasan para pelaku komuter diakui lebih rendah dibandingkan dengan pekerja lainnya yang tidak melakukan komuter.

Diener (dalam Asih, 2015) mengatakan bahwa ada beberapa aspek-aspek kepuasan hidup, yang pertama adalah evaluasi kepuasan hidup secara global, yaitu kepuasan hidup yang dimaksudkan untuk mempresentasikan penilaian individu yang secara umum terhadap kehidupannya dan evaluasi kepuasan pada ranah tertentu, yaitu merupakan kepuasan dalam kehidupan yang berfokus pada penilaian pada aspek yang lebih spesifik.

Tujuan pada penelitian ini, kami ingin mengetahui lebih lanjut apakah terdapat perbedaan tingkat kepuasan hidup pada masyarakat yang berkerja secara komuter dengan yang tidak secara komuter.

\section{METODE}

Desain penelitian. Penelitian ini menggunakan pendekatan non-eksperimental. Penelitian ini bersifat deskriptif yaitu penelitian yang bertujuan untuk mengetahui perbedaan kepuasan hidup antara pekerja yang komuter dan pekerja yang tidak komuter.

Partisipan penelitian. Partisipan penelitian ini secara keseluruhan terdiri atas 94 partisipan pekerja laki-laki maupun pekerja perempuan yang bertempat tinggal di wilayah Bogor. Dengan 38 partisipan komuter dengan rentang usia 18-60 tahun, dan 56 partisipan tidak komuter dengan rentang usia 18-60 tahun.

Teknik pengambilan data. Pengambilan sampel dalam penelitian ini dilakukan dengan menggunakan metode accidental sampling, sementara pengambilan data dengan menggunakan kuesioner.

Instrumen penelitian. Kepuasan hidup (Life Satisfaction) diukur dengan Satisfaction With Life Scale (SWLS) yang dikembangkan Diener, dkk. (1985). Alat ukur ini terdiri dari lima item. 
Lima item ini diberi skala dari $1=$ Sangat tidak setuju hingga $6=$ Sangat setuju. Contoh item alat ukur ini adalah, "Saya merasa puas dengan kehidupan saya". Semua partisipan telah diberikan inform concent sebelumnya merespon skala yang diberikan.

\section{HASIL}

\section{Tabel 1. Skor Kepuasan Hidup Pekerja}

Komuter dan yang Bukan

\begin{tabular}{ccc}
\hline Kepuasan hidup & $\boldsymbol{M}$ & $\boldsymbol{S D}$ \\
\hline $\begin{array}{c}\text { Pekerja komuter } \\
\begin{array}{c}\text { Pekerja bukan } \\
\text { komuter }\end{array}\end{array}$ & 56,9816 & 18,18808 \\
\hline
\end{tabular}

Meskipun dari nilai mean kepuasan hidup pekerja komuter lebih rendah dibanding yang bukan, dari uji independent sample t-test menunjukkan bahwa tidak terdapat perbedaan kepuasan hidup yang signifikan antara pekerja komuter $(M=56.98, S D=18.19)$ dibandingkan dengan pekerja bukan komuter $(M=57.56, S D=$ 10.64), $t(94)=-0.19, p=0.85$.

Kemudian ditemukan pula bahwa tidak terdapat hubungan antara skor kepuasan hidup dengan persepsi jarak tempat kerja dan rumah dengan $r(94)=0.13, p=(\mathrm{ns})$.

\section{DISKUSI}

Hasil penelitian kami menunjukkan tidak ada beda tingkat kepuasan hidup antara pekerja komuter dengan tidak komuter. Temuan lain juga menunjukkan bahwa tidak terdapat asosiasi antara persepsi jarak antara rumah dan tempat kerja dengan kepuasan hidup. Temuan ini menarik karena tidak sejalan dengan dengan penelitian yang dilakukan oleh Lachman, Saryska, Kannen, Stavrou, dan Montag (2017) dan penelitian yang dilakukan oleh Rahmadana (2014) yang mengatakan bahwa pekerja bukan komuter memiliki tingkat kepuasan hidup yang lebih tinggi dibandingkan pekerja komuter. Hal ini dikarenakan pekerja komuter harus menghabiskan waktu di perjalanan. Tentunya kondisi ini mengurangi banyak hal yang seharusnya bisa dilakukan oleh mereka bersama keluarga. Meski demikian temuan sebelumnya menunjukkan pekerja komuter masih memiliki kepuasan hidup yang relatif tinggi karena mereka menerima kompensasi finansial dari perusahaan tempat mereka bekerja (Lachman, Saryska, Kannen, Stavrou, \& Montag, 2017).

Temuan penelitian ini yang menunjukkan bahwa persepsi jarak antara rumah dan tempat bekerja dengan kepuasan hidup, agak berbeda dengan temuan Olsson, Gärling, Ettema, Friman, dan Fujii (2013) di daerah perkotaan Swedia. Olsson, dkk. (2013) menemukan bahwa perjalanan kerja yang lebih lama dapat meningkatkan pengaruh positif atau menangkal stres dan kebosanan.

Dari penelitian ini bisa disimpulkan bahwa menjadi pekerja komuter di daerah urban masih memiliki kemungkinan untuk memiliki kepuasan hidup yang baik. Salah satu faktor yang mungkin bisa dipertimbangkan adalah bagaimana mengisi perjalanan yang cukup lama dari rumah ke tempat kerja atau sebaliknya dengan kegiatan yang bermakna. Hal ini penting karena kepuasan terkait perjalanan kerja 
berkontribusi terhadap kebahagiaan seorang pekera komuter (Olson, dkk., 2013).

\section{DAFTAR PUSTAKA}

Asih, N. S., Yuliadi, I., \& Karyanta, N. A. (2015). Hubungan antara konsep diri dan religiusitas dengan kepuasan hidup pada lansia di desa rendeng kabupaten Kudus. Jurnal Ilmiah Psikologi Candrajiwa, 4(1).

Diener, E., Emmons, R. A., Larsen, R. J., \& Griffin, S. (1985). The Satisfaction With Life Scale. Journal of Personality Assessment, 49, 1.

Irawan, H. \& Pragesari, N. N. (2014). Statistik Komuter Jabodetabek (hasil survey komuter Jabodetabek 2014 (pp. 7).

Badan Pusat Statistik.

Lachman, B., Saryska, R., Kannen, C., Stavrou, M., \& Montag, C. (2017). Commuting, life satisfaction and internet addiction. International journal of environtmental research and public health, 14(10), 1176.

Olsson, L. E., Gärling, T., Ettema, D., Friman, M., \& Fujii, S. (2013). Happiness and satisfaction with work commute.

Social indicators research, 111(1), 255-263.

Rahmadana, M. F. (2014). Karakteristik Komuter dan Kualitas Hidup. Jurnal Ekonomikawan, 14(01), 1-8.

Sari, H. P. (2017). Profil masyarakat commuter di dusun sungai sibam desa karya indah kecamatan tapung kabupaten Kampar. Jurnal online mahasiswa fakultas ilmu sosial dan politik Universitas Riau, 4(1), 115.

Setyodhono, S. (2017). Faktor yang mempengaruhi pekerja komuter di jabodetabek menggunakan moda transportasi utama. Warta penelitian perhubungan, 29(1), 21-32.

Warsida, R. Y., Adioetomo, S. M., \& Pardede, E. (2013). Pengaruh variabel sosioDemografis terhadap mobilitas ulangalik di Jabodetabek. Jurnal Ekonomi dan Pembangunan Indonesia, 13(2), 159-176. 